\title{
Characteristics of the rumen proteolysis of fraction I (18S) leaf protein from lucerne (Medicago sativa $\mathrm{L}$ )
}

\author{
BY J. H. A. NUGENT* AND J. L. MANGAN \\ Department of Biochemistry, ARC Institute of Animal Physiology, Babraham, \\ Cambridge CB2 4AT
}

(Received 22 September 1980 - Accepted 21 October 1980)

1. The rate of proteolysis of fraction I (18S) leaf protein in the rumen of sheep and cattle was affected by diet and the rate on fresh lucerne (Medicago sativa $\mathrm{L}$ ) was three to nine times the rate on a hay + concentrate diet.

2. Simultaneous rumen fernientations in vivo and in an artificial rumen showed that the rates of proteolysis of fraction $I$ in vitro was approximately $80 \%$ of the rates in sheep.

3. Using ${ }^{14} \mathrm{C}$ uniformly-label ed fraction I protein at low concentrations, proteolysis exhibited lst-order kinetics. Over a wide range of protein concentrations the velocity $v$. substrate concentration curve showed Michaelis-Menten characteristics typical of an enz yme-catalysed reaction. With rumen fluid from a hay + concentrate-fed sheep the maximum velocity was $2.6 \mathrm{mg}$ protein nitrogen $/ \mathrm{l}$ per min and the Michaelis constant was $75 \mathrm{mg}$ nitrogen $/ 1$.

4. Rapid adsorption of ${ }^{14} \mathrm{C}$-labelled fraction 1 protein onto bacterial cells preceded proteolysis.

5. Sucrose-density-gradient analysis showed initial incorporation of ${ }^{14} \mathrm{C}$ from protein into rumen bacteria followed by partial transfer to rumen protozoa.

6. No peptides were detectec during proteolysis showing that the rate-limiting step occurred during the initial stages of proteolysis. Only small amounts of free amino acids were released except for leucine, isoleucine, valine and ornithine, which showed significantly increased levels.

7. Volatile fatty acids were the main ${ }^{14} \mathrm{C}$-labelled end products and were rapidly produced in descending concentrations: acetate $>$ prop: onate $>3$-methyl +2 -methyl butyrate $>$ butyrate $>$ isobutyrate $>$ valerate.

The proteolysis of soluble proteins in the rumen and subsequent fermentation of the released amino acids has long beer recognized as a cause of serious loss of energy (Blaxter \& Martin, 1962) and nitrogen (Chalmers et al. 1954) to sheep and cattle. Recent proposals by the Agricultural Research Council to formulate protein requirements for production have stressed the importance of assessing the proportions of degradable and undegradable food proteins reaching the small intestines (Miller et al. 1977; Roy et al. 1977). Similar systems proposed by Burroughs et al. (1974) and the computer simulated model of Black et al. (1981) have a requirement for the measurement of rumen degradation of proteins. Solubility is a major factor in the rapid proteolysis of dietary proteins (McDonald \& Hall, 1959; Henderickx \& Martin, 196.3), but Mangan (1972) has shown that two soluble proteins, casein and ovalbumin degrade in the bovine rumen at different rates, casein with a half-life of less than $20 \mathrm{~min}$ and ovalbum in with a half-life of approximately $180 \mathrm{~min}$. It was suggested that the difference in rates was due to structural differences in the two proteins. Mahadevan et al. (1980) have shown that soluble proteins labelled by azo substitution are degraded in vitro at different rates by suspensions of Bacteroides amylophilus and rumen fluid.

In the present work fraction I leaf protein was chosen as a suitable substrate for detailed studies on the mechanism of proteolysis. It is the major soluble protein of green leaves and functions as the ribulose-1,5-diphosphate carboxylase (EC 4.1 1.1.39) of chloroplasts. Its composition varies little between plant species, its properties have been studied extensively (for review, see Kawashima \& Wildman, 1970) and it is readily prepared uniformly labelled with ${ }^{14} \mathrm{C}$ by growing plarts in an atmosphere containing ${ }^{14} \mathrm{CO}_{2}$. It is probably the most abundant protein of the natural world and comprises $30-40 \%$ of the leaf protein of lucerne

* Present address: Department of Botany and Microbiology, University College London, Gower Street, London WCIE 6BT. 
(Medicago sativa L) (McArthur \& Miltimore, 1961). During mastication of herbage by cattle, fraction $I$ is readily released from plant tissues and is freely available to the rumen microflora in large amounts (Mangan et al. 1976). Preliminary communications of some of the results have been given (Nugent \& Mangan, 1978; Mangan et al. 1977; Nugent, 1978).

\section{EXPERIMENTAL AND METHODS}

\section{Animals}

Two Clun Forest sheep with permanent rumen cannulas (Jarrett, 1948) were maintained on one of two diets $(a) 1000 \mathrm{~g}$ chaffed hay $+100 \mathrm{~g}$ crushed oats fed once daily at 09.00 hours and $(b) 2 \mathrm{~kg}$ fresh cut lucerne fed twice daily at 09.00 and 16.30 hours. Water was ad lib. At $l$ week before an experiment the sheep was put into a metabolism cage (Harrison, 1974) and offered the appropriate ration. Four dry Jersey cows were fitted with $50 \mathrm{~mm}$ flexible polyvinyl chloride cannulas closed with light-weight plugs made of Perspex (F. A. Harrison, unpublished results). The two diets used were (a) $1800 \mathrm{~g}$ chaffed hay $+250 \mathrm{~g}$ crushed oats $+100 \mathrm{~g}$ linseed cake or $(b) 13 \mathrm{~kg}$ freshly cut lucerne. The diets were fed twice daily at 09.00 and 16.30 hours. At least 1 week before an experiment the cattle were put into stalls and offered the required diets.

\section{In vivo experiments}

Experiments were carried out as described by Mangan \& West (1977) with continuous sampling of rumen fluid by pumping through a stainless-steel-mesh probe positioned in the rumen digesta in the mid-ventral sac. Protein, together with CrEDTA as a marker, was added in solution into the rumen through the cannula usually $5 \mathrm{~h}$ after commencement of feeding. Sampling was continued for a further $3 \mathrm{~h}$. Water was withheld for the $8 \mathrm{~h}$ of the experiment.

\section{In vitro experiments}

Two kinds of apparatus were used.

Artificial rumen. The capacity was $400 \mathrm{ml}$, approximately one-hundreth that of a cow's rumen volume, one-tenth that of a sheep. The apparatus is shown in Plate 1. Before use the apparatus was brought approximately to working temperature and gassed out thoroughly with $\mathrm{N}_{2}-\mathrm{CO}_{2}(95: 5, \mathrm{v} / \mathrm{v})$. Rumen fluid was withdrawn from the rumen under conditions ensuring that no contact with air occurred. The rumen fluid was not strained or treated further, and avoiding ingress of air the sample was transferred to the gassed out artificial rumen by gentle squeezing of the inverted sampler bottle. After pre-incubation and equilibration for $1 \mathrm{~h}$, a solution of the protein to be examined together with CrEDTA as marker was added. When comparison of in vitro and in vivo proteolysis was required, the same proportion of protein: CrEDTA but 100-fold amounts were added to the cow from which the rumen fluid was taken or 10-fold in the instance of a sheep. Samples were removed periodically with a hyperdermic syringe or continuously with a peristaltic pump. In both instances a volume of synthetic parotid saliva (McDougall, 1948) equal to the sample taken was added to the artificial rumen to maintain its volume. Dilution was kept approximately to that observed in a cow at this time after feeding i.e. 7-10\%/h (Mangan, 1972). Sampling was continued for a further $3 \mathrm{~h}$.

Warburg apparatus. With stringent precautions against entry of oxygen and with rapid transfer of samples of rumen fluid in an atmosphere of $\mathrm{N}_{2}-\mathrm{CO}_{2}(95: 5, \mathrm{v} / \mathrm{v})$ it was possible to carry out proteolysis reactions on $4-5 \mathrm{ml}$ rumen fluid i.e. at approximately oneten-thousandth the volume of a cow and one-thousandth that of a sheep. Resazurin supplier was used as a redox indicator in these experiments. The apparatus used was a circular Warburg (E. Braun, Melsungen). It was not possible to subsample the Warburg reaction vessels but a series was set up sufficient to take one reaction vessel for each time of reaction.

Samples from both the artificial rumen and the Warburg apparatus were rapidly cooled 
in an ice-bath to stop further enzymic action and centrifuged at $10000 \mathrm{~g}$ for $20 \mathrm{~min}$ to obtain cell-free rumen fluid for analysis.

\section{Preparations of fraction I leaf protein}

Large-scale preparations were made from fresh lucerne leaves by modification of the method of Jones \& Mangan (1976). Batch treatment of leaf extracts at pH 6.85 to $62.5^{\circ}$ for $10 \mathrm{~min}$ in the original method was replaced by pumping through a stainless-steel coil immersed in a water-bath maintained at $62.5^{\circ}$ at a rate which provided a time of passage of $10 \mathrm{~min}$. Crude fraction I was precipitated with ammonium sulphate $(350 \mathrm{~g} / \mathrm{l})$ purified on an 81 Sephadex G75 column and the fraction I stored as a suspension in ammonium sulphate $(500 \mathrm{~g} / \mathrm{l})$ at $0^{\circ}$ or lyophilized after dialysis against $0.05 \mathrm{M}$-phosphate, $\mathrm{pH} 7.4$ and stored at $-20^{\circ}$.

${ }^{14} \mathrm{C}$-labelled fraction. I was prepared from lucerne grown in ${ }^{14} \mathrm{CO}_{2}$ in a growth cabinet described by Dawson $\delta$ Hemington (1974). The young seedlings were put into the apparatus when the first trifoliate leaf had been formed and were grown for approximately 3 weeks before harvesting. The leaves were cut into small pieces with scissors and macerated in $20 \mathrm{ml}$ Elvehjem glass homogenizers into ice-cold $0.05 \mathrm{M}$-phosphate buffer with the addition of sodium isoascorbate $(1 \mathrm{~g} / \mathrm{l}), 10^{-3} \mathrm{M}$-sodium diethyl dithiocarbamate and $10^{-3} \mathrm{M}$-2-mercaptoethanol (Jones \& Mangan, 1976). The macerate was strained through a single layer of muslin to remove coarse fibres and centrifuged at $10000 \mathrm{~g}$ for $30 \mathrm{~min}$ at $0^{\circ}$. The supernatant fraction was precipitated with ammonium sulphate $(350 \mathrm{~g} / \mathrm{l})$ and spun at $10000 \mathrm{~g}$ for 30 min at $0^{\circ}$. The protein pellet was dissolved in $10 \mathrm{ml}$ extraction buffer and without delay freed from small-molecular-weight compounds, in particular phenolic substances, by chromatographing on at $25 \times 600 \mathrm{~mm}$ Sephadex G50 column equilibrated with extraction buffer. The column effuent was monitored for protein by absorption at $280 \mathrm{~nm}$, for ammonium by Nessler's reagent and ${ }^{14} \mathrm{C}$ by counting on a liquid-scintillation counter. The soluble protein fractions were combined, precipitated with ammonium sulphate $(350 \mathrm{~g} / \mathrm{l})$ and centrifuged. The protein pellet was dissolved in extraction buffer and further purification from any remaining fraction 2 proteins was obtained by chromatography on a $26 \times 600$ mm Sephadex G200 column monitoring the effluent as described previously. The fraction I-containing fractions were combined, made up to $350 \mathrm{~g}$ ammonium sulphate $/ 1$ and stored as a suspension at $4^{\circ}$.

\section{Analytical methods}

Total N, total soluble N, non-protein-N and ammonia- $\mathrm{N}$ were determined by AutoAnalyzer methods as described by Mangan \& West (1977). Soluble protein-N was calculated as the difference between total soluble $\mathrm{N}$ and non-protein $\mathrm{N}$. Polyethylene glycol (molecular weight 4000; PEG) was measured by the turbidimetric method of Hydén (1956). CrEDTA was measured by atomic absorption spectrometry using a Pye Unicam SP191 at $358 \mathrm{~nm} .{ }^{14} \mathrm{C}$ radioactivity was measured by liquid scintillation using 'Fiscint' scintillation fluid (Fisons Chemicals Ltd) in a Nuclear Chicago Unilux II counter. Quench correction was by external standards. Amino acid a nalysis was carried out with a modified Locarte automatic analyser using the recommended lithium buffers for biological samples. The chromatographic column $(10 \times 500 \mathrm{~mm})$ was packed with $8 \%$ cross-linked sulphonated polystyrene microbeads mean diameter $12 \mu \mathrm{m}$. Before passing into the ninhydrin analytical system the column effluent was passed thro $\mathrm{ugh}$ a spiral radioactive-scintillation detector (Mangan \& Bounden, 1965). The spiral was packed with 60 mesh scintillator-grade anthracene mixed with an equal volume of 60 mesh glass ballotini. This simple device measured ${ }^{14} \mathrm{C}$ radioactivity in the range 1-50 $\mathrm{nCi}$ for each amino acid peak. The peak areas were measured manually by triangulation and a series of ${ }^{14} \mathrm{C}$-labelled amino acid standards gave a linear response in this range. 
Samples for analysis were deproteinized by the addition of an equal volume of sulphosalicylic acid $(100 \mathrm{~g} / \mathrm{l})$ or by passage through ultrafiltration centrifuge cones (Amicon Corp., Lexington, Mass, USA); CF24 with cut-off at molecular weight 25000 or CF50 with cut-off at molecular weight 50000 . Volatile fatty acids (VFA) were extracted from centrifuged rumen fluid by acidification with $\mathrm{HCl}$ and extracting three times with 10 volumes of diethyl ether. The extracts were analysed in a Pye 104 gas chromatograph with Chromasorb 101 column. ${ }^{14} \mathrm{C}$ radioactivity was measured with a gas-flow counter (James \& Piper, 1963); minimum peak detected was 180 disintegrations/min.

\section{Pdlyacrylamide gel electrophoresis}

Slab gel electrophoresis was carried out using the vertical apparatus of Reid \& Bieleski (1968) with 0.10 or $0.05 \mathrm{M}$-Tris-glycine buffer $\mathrm{pH} 8.5$ in both gels and electrode chambers, and electrophoresing for $1-2 \mathrm{~h}$ at a constant current of $25 \mathrm{~mA}$. Gels of 75,100 and $125 \mathrm{~g}$ polyacrylamide/l were made by dilution of a stock solution containing $150 \mathrm{~g}$ acrylamide/l and $3 \mathrm{~g}$ methylene bis-acrylamide/l. The de-aerated solution was polymerized with $10 \mathrm{~g}$ ammonium persulphate $/ 1$ and $10 \mathrm{~g}$ tetramethylene ethylene diamine/ 1 . The samples (10-25 $\mu \mathrm{l})$ were applied in sucrose solution $(100 \mathrm{~g} / \mathrm{l})$ containing bromophenol blue as a front marker. After running the gels were stained for $30 \mathrm{~min}$ with $0.25 \mathrm{~g}$ Coomassie Blue G250/1 (Gurr; High Wycombe) acetic acid-methanol-water $(7: 28: 65$, v/v) and destained in the same solvent for $24 \mathrm{~h}$ with several changes of solvent. Coomassie Blue colour yield was quantitative from 0 to $0.25 \mathrm{mg}$ protein/ml. For higher concentrations $0.5 \mathrm{~g}$ Naphthalene Black/l was quantitative up to $2 \mathrm{mg}$ fraction I protein $/ \mathrm{ml}$. The gels were scanned by a Quick-Scan Jr (Helena Co., Beaumont, Texas, USA).

Sodium dodecyl sulphate (SDS) gels were carried out as described previously except that $1 \mathrm{~g} \mathrm{SDS} / 1$ and $0.1 \mathrm{ml} 2$-mercaptoethanol/l were added to the buffer for gels and electrode vessels. Samples for denaturing to subunits were treated with $10 \mathrm{~g}$ SDS/l and $1 \mathrm{~g}$ 2-mercaptoethanol/1 for $30 \mathrm{~min}$ at $70^{\circ}$.

\section{Sucrose density gradients}

Particulate matter from rumen fluid was separated by centrifugation on discontinuous sucrose gradients $(350,450,500,650$ and $750 \mathrm{~g} / \mathrm{l})$ for $1 \mathrm{~h}$ at $300 \mathrm{~g}$ at $0^{\circ}$ as described by Mangan \& West (1977). To measure ${ }^{14} \mathrm{C}$ incorporation, portions of each fraction were treated with an equal volume of $20 \mathrm{~g}$ SDS $/ 1+10 \mathrm{M}$-urea $+50 \mathrm{mM}$ 2-mercaptoethanol for 30 min at $70^{\circ}$ (Shafa \& Salton, 1960). The samples were then counted in a liquid scintillation counter as above.

\section{Gel filtration}

Chromatographic colums of Sephadex G200, G75, G50, G25 and G10 (Pharmacia Ltd, Uppsala) were run at $4^{\circ}$ for fractionation of proteins and peptides of a wide range of molecular weights. Fractionations with SDS treatment were run at room temperature to avoid precipitation of SDS.

\section{Rumen protozoa}

Mixed populations of protozoa from strained rumen fluid were isolated by differential centrifugation and washing as described by Coleman (1975).

\section{RESULTS \\ Rates of proteolysis}

Effect of diet. Because the rumen microflora changes with the diet of the animal the proteolytic activity in the rumen was measured on two diets. Fig. 1 shows the degradation of pure fraction I in the rumen of a sheep. The protein was administered $5 \mathrm{~h}$ after feeding the normal ration, at which time the soluble protein content of the rumen fluid was low 


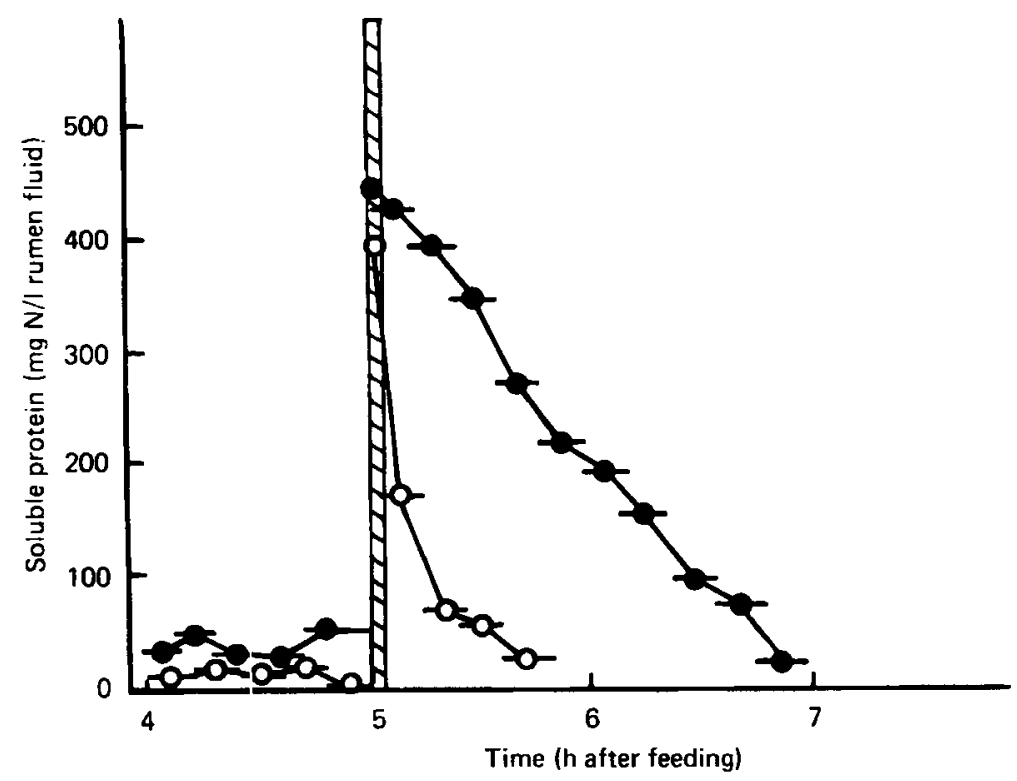

Fig. 1. Proteolysis of fraction I leaf in the rumen of a sheep when fed on two different diets. Fraction I protein + CrEDTA were added ( $20 \mathrm{ml}$ solution) $5 \mathrm{~h}$ after feeding. (O), Fresh lucerne (Medicago sativa $\mathrm{L}$ ); (O), hay + concentrate. Horizontal bars represent 12 min continuous sampling periods. $Q$, time of addition of protein and includes the initial protein concentraton calculated from rumen volume and quantity of protein addec.

and fairly constant. C:EDTA marker was added with the protein solution and by extrapolation of $\mathrm{Cr}$ concentrations the rumen volume was calculated and hence the expected initial concentration of fraction $I$ in the rumen fluid. The subsequent points were measured experimentally and corrected for dilution by CrEDTA concentrations. On the hay + concentrate diet the rate of Jroteolysis of fraction I was relatively slow with an initial velocity of $3.3 \mathrm{mg} \mathrm{N} / 1$ rumen fluid per min. After feeding on fresh lucerne for 1 week the rate of proteolysis had increased at least 9-fold with an initial velocity $>30 \mathrm{mg} \mathrm{N} / 1 \mathrm{per} \mathrm{min}$. The increased rate on the lucerne diet was confirmed by the experiments shown in Table 1 and the mean value was approximately six times that observed on a hay + concentrate diet. This represents a large increase in proteolytic activity towards fraction I protein, the major soluble protein of lucerre, and suggests either a corresponding increase in total bacterial numbers or, more probably, a selective increase in the organisms able to utilize fraction I effectively. In Expts 1 and 2, Table 1, the particulate $\mathrm{N}$ (obtained by centrifuging at $10000 \mathrm{~g}$ for $15 \mathrm{~min}$ ) of the rumen fluid had a mean $( \pm \mathrm{SE})$ value of $740 \pm 77 \mathrm{mg} \mathrm{N} / 1$ on the hay + concentrate diet and $923 \pm 61 \mathrm{mg} \mathrm{N} / \mathrm{l}$ on the lucerne diet indicating no large increase in total bacteria $\mathbf{N}$. Ex.planation of the 3-9-fold increase in proteolysis probably lies in increased numbers of proteolytic organisms such as Bacteroides $\mathbf{R} 8 / 4$ recently isolated from the rumen (Hazlewood \& Nugent, 1978; Hazlewood et al. 1981).

Validity of in vitro measurement of proteolysis. To avoid the use of radioactive and expensive proteins in whole animals, comparisons were made in the artificial rumen and Warburg apparatus coricurrently with measurement of proteolytic rates in the animal from which rumen fluid was withdrawn. Fig. 2 shows the rate of breakdown of fraction I protein in the rumen of a sheep fed on a hay + concentrate diet compared with the rate in the artificial rumen. The sheep was fed at 09.00 hours, and $4 \mathrm{~h}$ later approximately $300 \mathrm{ml}$ rumen fluid was transferred to the artificial rumen and incubation commenced. At $5 \mathrm{~h}, 18 \mathrm{~g}$ fraction 


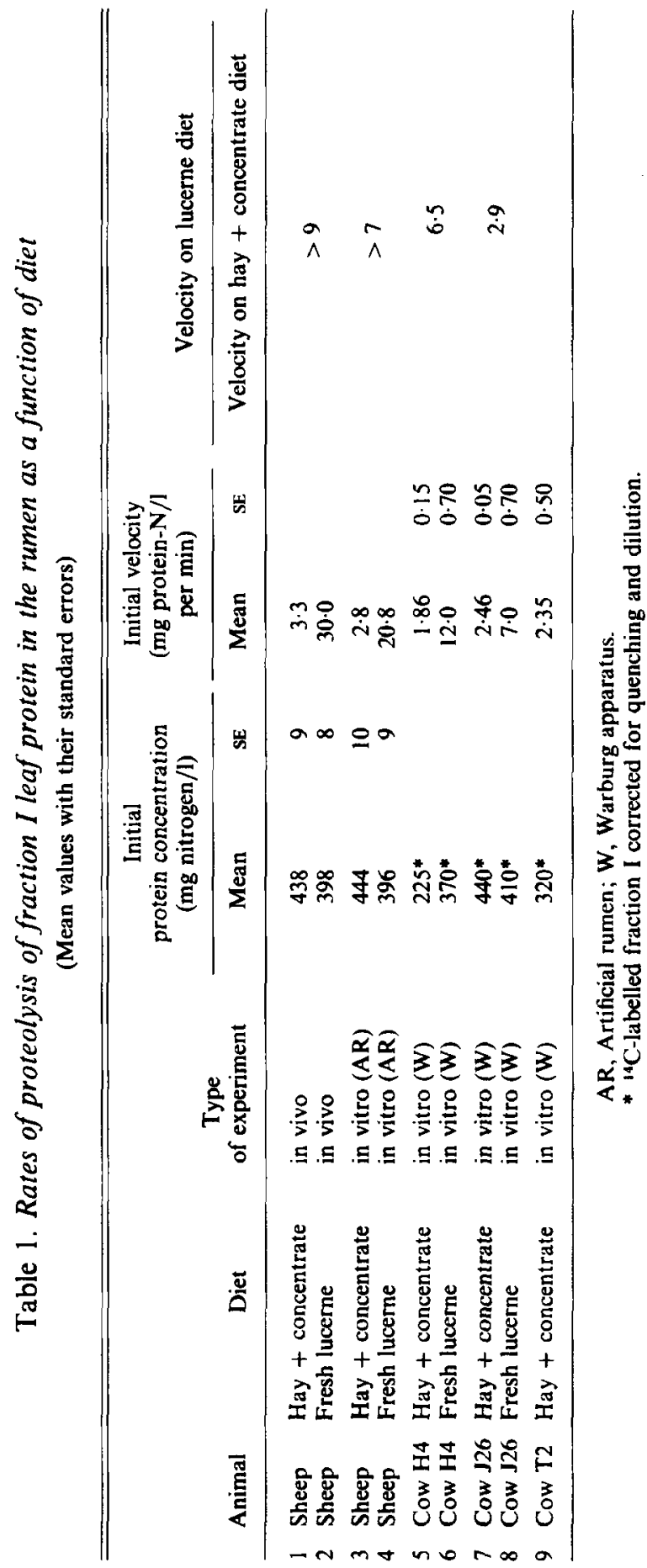




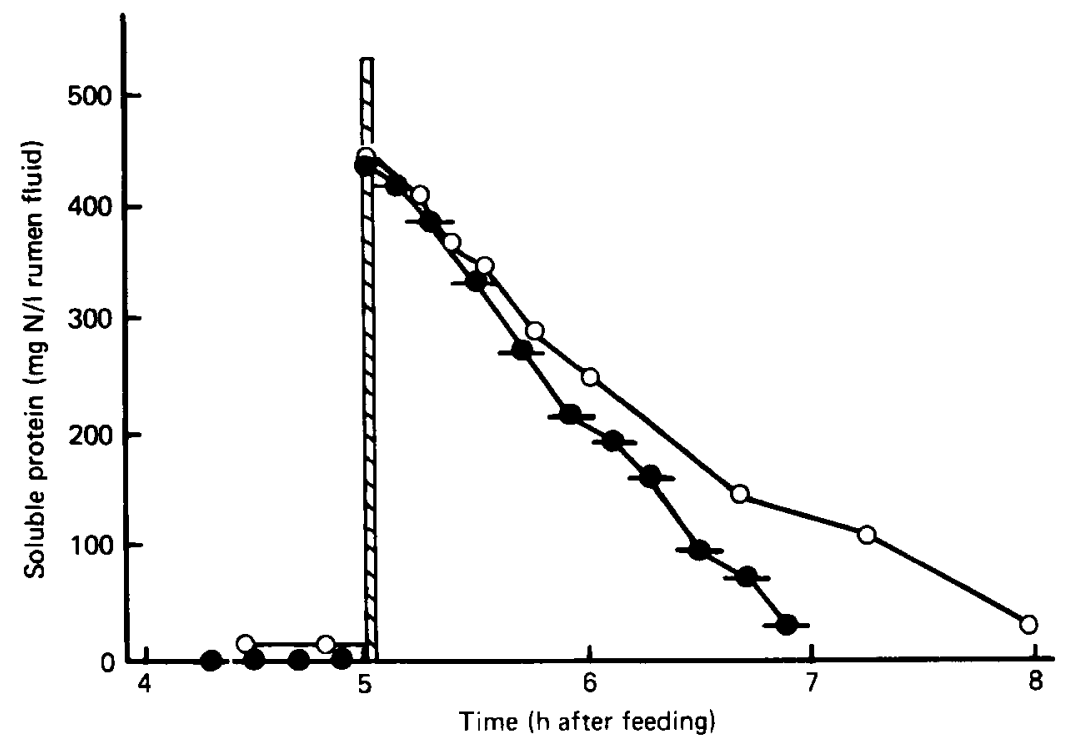

Fig. 2. Comparison of rumen proteolysis of fraction I leaf protein in vivo and in vitro. Sheep was fed on hay + concentrate diet. $4 \mathrm{~h}$ after feeding approximately $300 \mathrm{ml}$ rumen fluid was withdrawn and incubation started in artificial rumen. At $5 \mathrm{~h}$ after feeding fraction $\mathrm{I}+\mathrm{CrEDTA}$ was added to both the rumen of the sheep $(O)$ and to the artificial rumen $(O)$. Horizontal bars represent the $12 \mathrm{~min}$ sampling periods and $\mathrm{Q}$ time :equired for additions to the rumens and includes calculated points for initial protein concentration.

Table 2. Comparison of in vivo and in vitro rates of proteolysis in sheep

\begin{tabular}{|c|c|c|c|c|c|c|c|}
\hline \multirow[b]{2}{*}{ Diet } & \multirow[b]{2}{*}{ Substrate } & \multirow[b]{2}{*}{ System } & \multicolumn{2}{|c|}{$\begin{array}{l}\text { Initial protein } \\
\text { concentration } \\
\text { (mg nitrogen } / 1)\end{array}$} & \multicolumn{2}{|c|}{$\begin{array}{l}\text { Initial velocity } \\
\text { of proteolysis } \\
\mathrm{mg} \mathrm{N} / \mathrm{l} \text { per min }\end{array}$} & \multirow{2}{*}{$\begin{array}{l}\text { In vitro } \\
\text { in vivo }\end{array}$} \\
\hline & & & Mean & SE & Mean & SE & \\
\hline $\begin{array}{c}\text { Hay }+ \\
\text { concentrates }\end{array}$ & $\begin{array}{c}\text { Fraction I } \\
\text { prctein }\end{array}$ & $\begin{array}{l}\text { in vivo } \\
\text { in vitro }(A R)\end{array}$ & $\begin{array}{l}438 \\
444\end{array}$ & $\begin{array}{r}9 \\
10\end{array}$ & $\begin{array}{l}3 \cdot 35 \\
2 \cdot 76\end{array}$ & $\overline{0.2}$ & 0.82 \\
\hline $\begin{array}{c}\text { Fresh } \\
\text { lucerne }\end{array}$ & $\begin{array}{c}\text { Fraction I } \\
\text { protein }\end{array}$ & $\begin{array}{l}\text { in vivo } \\
\text { in vitro }(A R)\end{array}$ & $\begin{array}{l}398 \\
396\end{array}$ & $\begin{array}{l}8 \\
9\end{array}$ & $\begin{array}{l}30 \cdot 0^{*} \\
20 \cdot 8^{*}\end{array}$ & - & 0.69 \\
\hline $\begin{array}{c}\text { Hay }+ \\
\text { concentrates }\end{array}$ & ca.sein & $\begin{array}{l}\text { in vivo } \\
\text { in vitro }(A R)\end{array}$ & $\begin{array}{l}386 \\
371\end{array}$ & $\begin{array}{l}13 \\
11\end{array}$ & $\begin{array}{l}16 \cdot 5 \\
20 \cdot 0^{*}\end{array}$ & $2 \cdot 0$ & $1 \cdot 21$ \\
\hline
\end{tabular}

AR, artificial rumen.

* Fast rates difficult to measure accurately.

I protein in $350 \mathrm{ml}$ artificial saliva was administered to the rumen of the sheep and $1 \mathrm{~g}$ fraction $I$ in $20 \mathrm{ml}$ synthetic saliva added to the artificial rumen. The fraction $I$ in the artifical rumen was labelled with ${ }^{14} \mathrm{C}$-labelled fraction I to a specific activity of 388 disintegrations/ min per mg protein-N $\mathrm{N}$. CrEDTA was used as a marker to calculate the rumen volume of the sheep $(6020 \pm 205 \mathrm{ml})$ and the artificial rumen $(317 \pm 8 \mathrm{ml})$. The artificial rumen showed an initial rate of protsolysis approximately $82 \%$ of the rate observed in the sheep and only slowed significantly ajter the first $2 \mathrm{~h}$. Other results in Table 2 show that the artificial rumen gives high rates of proteolysis approximating to those obtained with the intact animal. The Warburg apparatus gave values almost identical to the artificial rumen. 


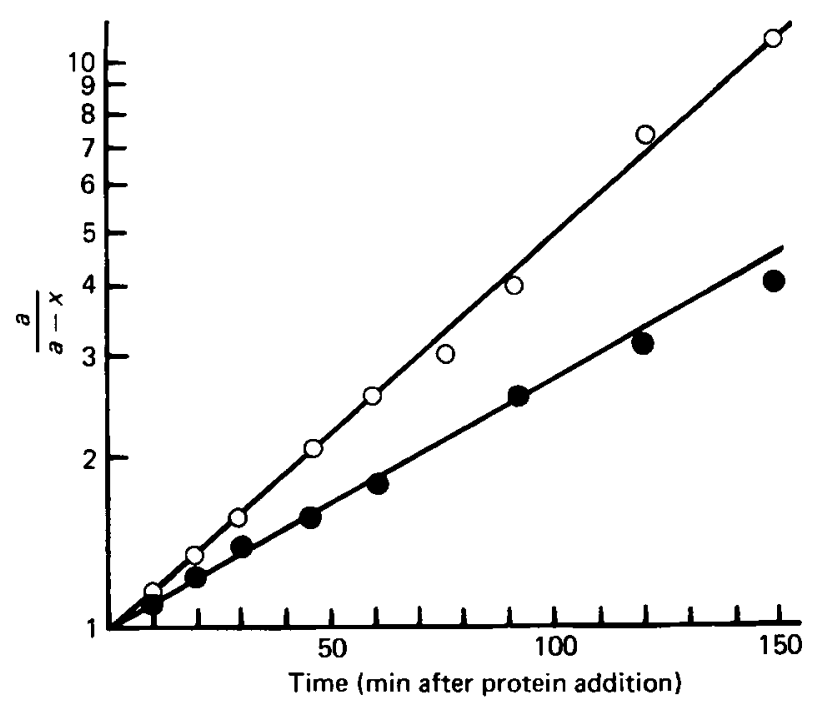

Fig. 3. Demonstration of 1 st order kinetics for in vitro proteolysis in bovine rumen fluid of ${ }^{14} \mathrm{C}$-labelled fraction I protein at low concentrations. $a$ is the initial ${ }^{14} \mathrm{C}$-labelled protein concentration, $x$ is the ${ }^{14} \mathrm{C}$-labelled protein degraded. $(\mathrm{O}-\mathrm{O}), 105 \mathrm{mg}$ nitrogen/l initial concentration; $\left(0_{-0}\right), 270 \mathrm{mg}$ nitrogen/l initial concentration.

Kinetics. By using ${ }^{14} \mathrm{C}$-labelled fraction I protein in the artificial rumen it was possible to study proteolysis at low concentrations with a high extent of accuracy. In Fig. 3 are shown the plots of $\log (a / a-x)$ (where $a$ is the initial ${ }^{14} \mathrm{C}$-labelled protein concentration and $x$ is the ${ }^{14} \mathrm{C}$-labelled protein degraded) $v$. time. Two low concentrations of fraction I show straight-line relationships characteristic of 1 st order reactions, with a high linear correlation of 0.99 . The high accuracy of these results is due to rapid mixing in the artificial rumen, the use of ${ }^{14} \mathrm{C}$-labelled protein and the absence of factors such as salivary proteins and transport of non-protein- $\mathrm{N}$ across the rumen epithelium expected in vivo. In all experiments where ${ }^{14} \mathrm{C}$-labelled protein was used an initial adsorption of protein by rumen particulate matter was observed and the initial concentration of protein $a$ was therefore calculated from the linear plot of protein concentration $v$. time and extrapolation back to zero time. This adsorption will be discussed later (p. 49).

At higher protein concentrations the initial rate of proteolysis showed some zero order characteristics (Fig. 2). The effect of initial protein concentration over a wide range on the velocity of proteolysis was therefore investigated. In one experiment the initial substrate $\left({ }^{14} \mathrm{C}\right.$-labelled fraction I) concentration ranged from approximately 80 to $430 \mathrm{mg} \mathrm{N} / \mathrm{l}$. Initial velocities of proteolysis were determined and when plotted $v$. fraction I initial concentration showed a typical Michaelis-Menten curve with a maximum velocity of approximately $2.6 \mathrm{mg} \mathrm{N} / \mathrm{min}$ per 1 rumen fluid (Fig. 4); $\frac{1}{2} V_{\max }$ was $1.3 \mathrm{mg} \mathrm{N} / \mathrm{min}$ per 1 and the corresponding Michaelis constant $\left(K_{m}\right)$ was $70-80 \mathrm{mg} \mathrm{N} / \mathrm{l}$.

Also plotted in Fig. 4 are fourteen other determinations spread over a period of 2 years. Three cows were used on different rations during this time, but all determinations were made when the animals were stabilized on the hay + concentrate ration. The points fall quite well on the same Michaelis curve with $V_{\max }$ and $K_{m}$ values unchanged. The proteolytic characteristics of the rumen contents on the hay + concentrate diet therefore showed a remarkable constancy and this was in sharp contrast to the very large change in proteolysis (3-9-fold) observed when the diet was changed to fresh lucerne. 


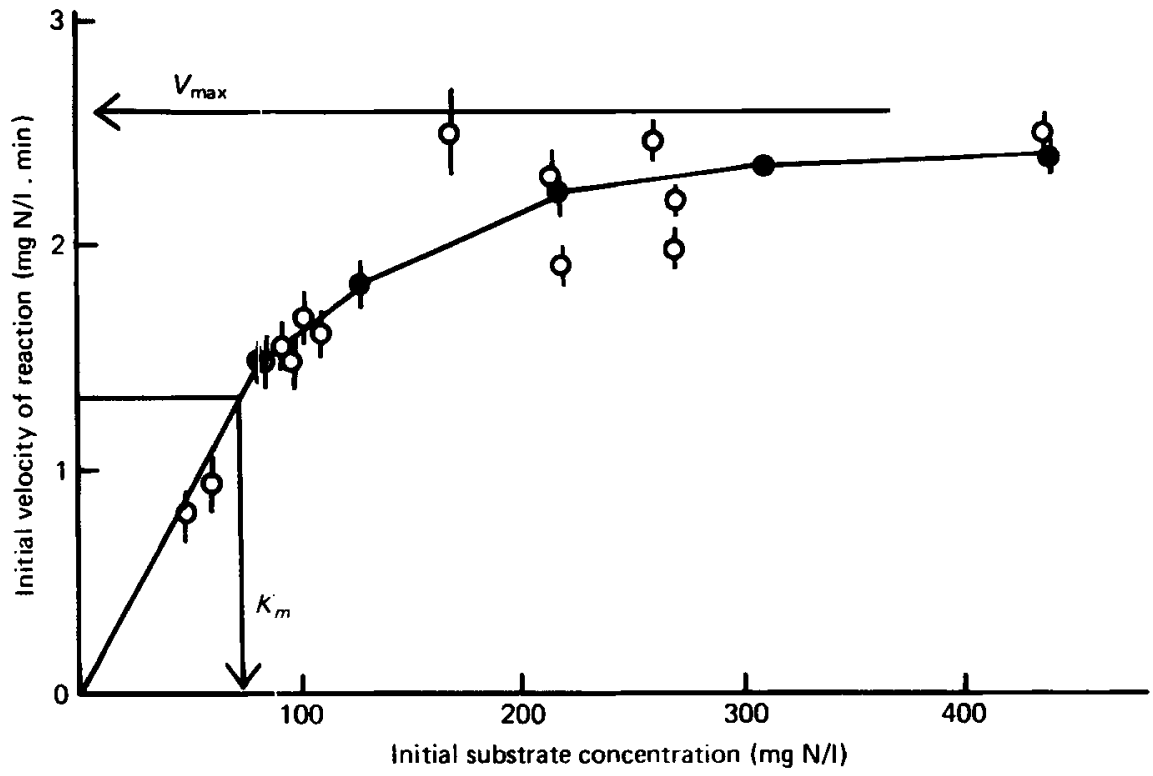

Fig. 4. Velocity $v$. substrate concentration curve for ${ }^{14} \mathrm{C}$-labelled fraction I proteolysis. (O), MichaelisMenten characteristics determined in duplicated fermentations of $\mathbf{3 0}$ min duration in vitro (Warburg apparatus), using rumen fluid from cows fed on hay + concentrate diet. ( $O$ ), random experiments in vitro (Warburg or artificial rurien) over a 2-year period using rumen fluid from cows fed on hay + concentrate diet. Vertical bars represent standard deviations. $V_{\max }$, maximum velocity; $K_{m}$ Michaelis constant.

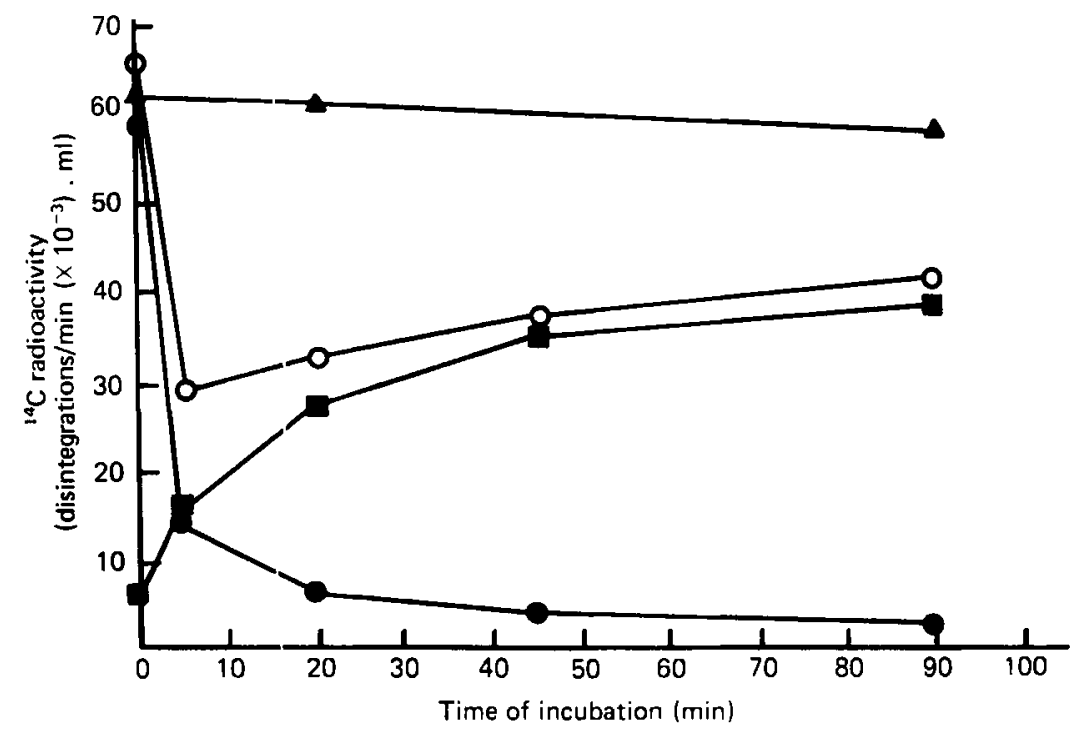

Fig. 5. In vitro proteolysis of ${ }^{14} \mathrm{C}$-labelled fraction I leaf protein showing initial adsorption of protein. Initial protein concentration $40 \mathrm{mg}$ nitrogen $/ 1 .{ }^{14} \mathrm{C}$ activity 65 disintegrations $/ \mathrm{min}\left(\times 10^{-3}\right)$ per ml. Bovine rumen fluid from lucerne (Mledicaga sativa $\mathrm{L}$ ) fed cow in $7 \mathrm{ml} \mathrm{Warburg}$ incubations at $39^{\circ}$. (A), Control with artificial saliva; $(O)$, total soluble ${ }^{14} \mathrm{C} ;(\mathrm{O})$, soluble protein ${ }^{14} \mathrm{C} ;(\mathbf{Q})$, non-protein ${ }^{14} \mathrm{C}$. 


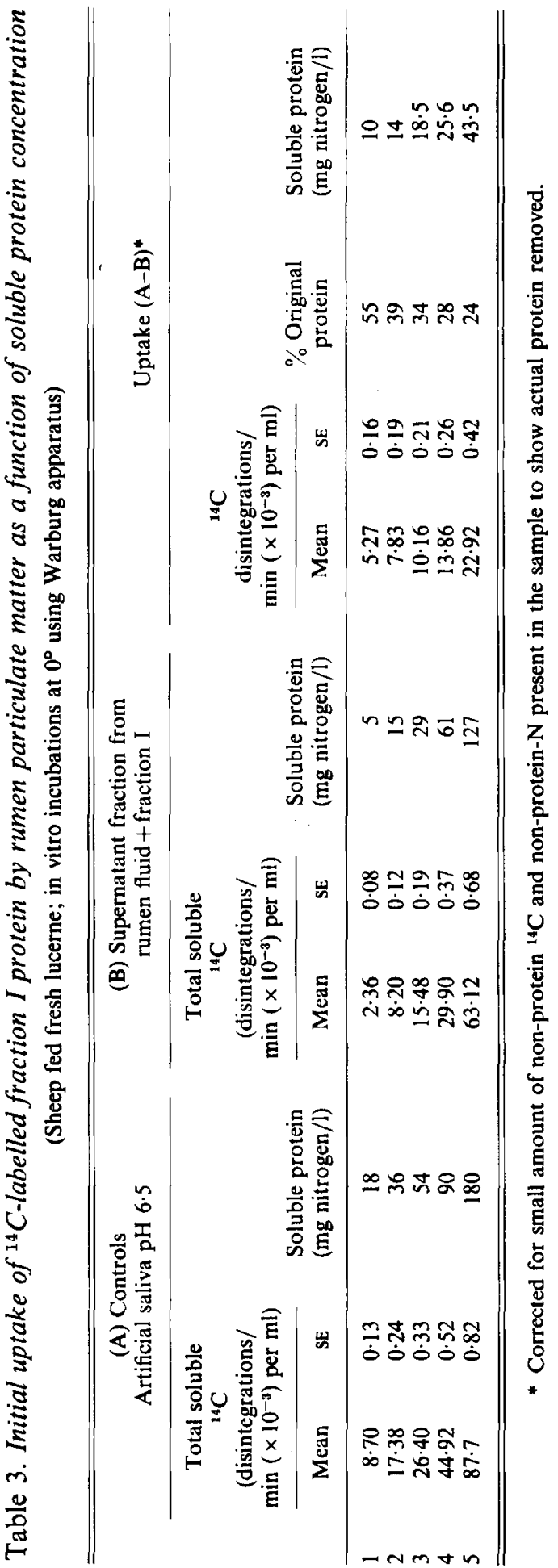


Table 4. Initial uptake* of ${ }^{14} \mathrm{C}$-labelled fraction I protein by crude rumen fluid from cow 5 h after feeding hay + concentrate diet

(Incubated for $30 \mathrm{~min}$ at $0^{\circ}$ after protein addition ( $<20 \mathrm{mg}$ nitrogen $/ 1 ; 105 \cdot 5$ disintegrations $/ \mathrm{min}$ $\left(\times 10^{-3}\right)$ per $\left.\mathrm{ml}\right)$ and centrifuged clear at $\left.10000 \mathrm{~g}\right)$

\begin{tabular}{|c|c|c|c|}
\hline \multirow[b]{2}{*}{ Incubation } & \multicolumn{2}{|c|}{$\begin{array}{c}\text { Total soluble } \\
{ }^{14} \mathrm{C} \text { after incubation } \\
\text { (disintegrations } / \mathrm{min} \\
\left.\left(\times 10^{-3}\right) \text { per } \mathrm{ml}\right)\end{array}$} & \multirow{2}{*}{$\begin{array}{c}\text { Uptake }{ }^{14} \mathrm{C}^{*} \\
\text { (disintegrations/min } \\
\left.\left(\times 10^{-3}\right) \text { per } \mathrm{ml}\right)\end{array}$} \\
\hline & Mean & $\mathbf{S E}$ & \\
\hline Artificial saliva, pH 6.7 & 106 & 0.86 & 0.0 \\
\hline Crude rumen fluid supernatant fraction & 103 & 0.79 & $2 \cdot 5$ \\
\hline $\begin{array}{l}\text { Crude rumen fluid supernatant fraction } \\
+ \text { Millex }+ \text { filtration }\end{array}$ & 105 & 0.83 & 0.5 \\
\hline $\begin{array}{l}\text { Crude rumen fluid supernatan: fraction } \\
+ \text { hay }\end{array}$ & 103 & $0 \cdot 87$ & $2 \cdot 5$ \\
\hline Crude rumen fluid & 56 & 0.55 & $49 \cdot 5$ \\
\hline Crude rumen fluid + ImM-EDTA & 56 & 0.58 & $49 \cdot 5$ \\
\hline Crude rumen fluid +15 mM-EDTA & 90 & 0.78 & $15 \cdot 5$ \\
\hline $\begin{array}{l}\text { Crude rumen fluid }+15 \mathrm{~mm} \text {-magnesium } \\
\text { sulphate }\end{array}$ & 85 & 0.72 & 20.5 \\
\hline $\begin{array}{l}\text { Crude rumen fluid }+1 \mathrm{ml} \text { toluene } \\
\text { (to } 6 \mathrm{ml} \text { incubation) }\end{array}$ & 56 & 0.57 & $49 \cdot 5$ \\
\hline $\begin{array}{l}\text { Crude rumen fluid }+2.5 \mathrm{~g} \text { sodium } \\
\text { dodecyl sulphate } / 1\end{array}$ & 105 & 0.84 & 0.5 \\
\hline $\begin{array}{l}\text { Crude rumen fluid + fraction ! } \\
\text { treated with formaldehyde }\end{array}$ & 70 & 0.68 & $35 \cdot 5$ \\
\hline $\begin{array}{l}\text { Mixed protozoa from rumen fluid } \\
\text { concentrated } 5 \text {-fold }\end{array}$ & 103 & $0 \cdot 86$ & $2 \cdot 5$ \\
\hline
\end{tabular}

- Initial uptake $=105.5$ disintegrations $/ \min \left(\times 10^{-3}\right)$ per $\mathrm{ml}-$ total soluble ${ }^{14} \mathrm{C}$.

+ Millex sterilizing filter; Millipore S.A., Molsheim, France.

¥ Treated with $240 \mathrm{~mm}$-formaldehyde for $24 \mathrm{~h}$ at room temperature and dialysed free from excess formaldehyde.

\section{Adsorption of fraction I protein onto rumen organisms}

The use of ${ }^{14} \mathrm{C}$-labelled fraction I protein enabled the rapid binding of fraction I to be observed. This is demonstrated in Fig. 5 during the proteolysis of low concentration ( $<40 \mathrm{mg} \mathrm{N} / \mathrm{l}$ ) of fraction I but with a high specific activity. Proteolysis is rapid and coupled with an immediate adsorption of ${ }^{14} \mathrm{C}$-labelled protein onto the particulate part of the rumen fluid. This is followed by a slow release of ${ }^{14} \mathrm{C}$ into the total soluble fraction as the protein is hydrolysed and the products partly released into the medium. The control, in which the protein was incubated with artificial saliva adjusted to $\mathrm{pH} 6.8$ with acetic acid at $39^{\circ}$, showed no appreciable breakdown of fraction $\mathrm{I}$. $\mathrm{N}$ analyses were not done in this experiment as the initial concentration, $<40 \mathrm{mg} \mathrm{N} / 1$, was too low to measure accurately.

The adsorption of protein occurred readily at $0^{\circ}$ and under these conditions proteolysis was kept to a minimum. Table 3 shows the effect of increasing concentrations of ${ }^{14} \mathrm{C}$-labelled fraction I protein on the initial uptake. Artificial saliva adjusted to $\mathrm{pH} 6.8$ was used in the control samples and no precipitation or loss of protein was observed. Crude rumen fluid adsorbed increasing amounts of ${ }^{14} \mathrm{C}$-labelled fraction I onto particulate matter with increasing concentrations of fraction I. The proportion of the initial fraction I which was adsorbed decreased, however, suggesting that adsorption sites were being saturated. The 
highest concentration in Table $3,180 \mathrm{mg} \mathrm{N} / \mathrm{l}$ is often exceeded in the rumen and the amount of adsorbed protein, $43.5 \mathrm{mg} \mathrm{N} / 1$ or $24 \%$ of the original protein, is a significant proportion of the soluble protein present.

Further information on the nature of the uptake of protein by rumen particles was given by a series of experiments shown in Table 4 . The rumen fluid was taken from a hay + concentrate-fed cow $5 \mathrm{~h}$ after feeding and ${ }^{14} \mathrm{C}$-labelled fraction I was added at a concentration of less than $20 \mathrm{mg} \mathrm{N} / 1$, but with high specific activity giving a count of $105.5 \times 10^{3}$ disintegrations $/ \mathrm{min}$ per $\mathrm{ml}$. Artificial saliva at $0^{\circ}$ caused no loss or precipitation of protein at $\mathrm{pH} 6.7$, the approximate $\mathrm{pH}$ of the rumen fluid. Rumen fluid supernatant fraction produced by centrifugation appeared to retain some proteolytic activity, but this was under conditions of very low protein concentrations and sterilizing filtration to remove all bacterial cells reduced it to a very low value. Protein uptake was low and the addition of ground hay to the rumen fluid supernatant fraction did not result in uptake of protein. Crude rumen fluid demonstrated a large uptake of ${ }^{14} \mathrm{C}$-labelled protein. Protozoal cells isolated from the rumen fluid and concentrated 5 -fold showed neither uptake of protein nor proteolysis and this strongly indicated that bacterial cells were the particles responsible for initial protein uptake. Reagents known to affect cell walls and membranes were found to affect uptake of protein and $15 \mathrm{~mm}$-EDTA and $15 \mathrm{~mm}$-magnesium ions markedly reduced uptake while $2.5 \mathrm{~g}$ SDS/l eliminated uptake. Treatment with toluene or cooling the rumen fluid for $2 \mathrm{~h}$ at $0^{\circ}$ had no effect. Mild treatment of fraction I with $240 \mathrm{~mm}$-formaldehyde for $24 \mathrm{~h}$ at $20^{\circ}$, insufficient to cause precipitation, caused a reduction in initial uptake and rate of proteolysis.

In separate experimets it was shown that once ${ }^{14} \mathrm{C}$-labelled fraction I was adsorbed by the rumen bacteria, it could not be displaced or show any exchange with casein, bovine serum albumin or cold fraction I in a second incubation. ${ }^{14} \mathrm{C}$-labelled compounds only returned to solution as low-molecular-weight products, as shown later (p. 51). Incubation of rumen fluid with casein, bovine serum albumin or cold fraction I before addition of ${ }^{14} \mathrm{C}$-labelled fraction I did significantly reduce the extent of uptake of ${ }^{14} \mathrm{C}$-labelled fraction I.

\section{Incorporation of proteolysis products by micro-organisms}

By incubating ${ }^{14} \mathrm{C}$-labelled fraction I of high specific radioactivity in vitro with rumen fluid and separating the rumen particulate matter on discontinuous sucrose density gradients it was possible to quantify the incorporation of protein by different groups of micro-organisms. Table 5 shows the results of two experiments on the two diets used. In both experiments the initial uptake of protein was a function mainly of the bacterial fractions, the small bacteria being more effective than the larger bacteria. In Expt A, as the incubation time increased the ${ }^{14} \mathrm{C}$ label in the small bacteria decreased and there was a corresponding increase in the protozoal fractions until the two bottom fractions contained $50 \%$ of the total ${ }^{14} \mathrm{C}$ count. Of the total ${ }^{14} \mathrm{C}$-labelled fraction I hydrolysed a maximum of $45 \%$ was incorporated into the particulate matter at $25 \mathrm{~min}$. The amount of ${ }^{14} \mathrm{C}$ lost as gas, measured as $\left({ }^{14} \mathrm{C}\right.$ added - (total soluble ${ }^{14} \mathrm{C}+$ total particulate $\left.{ }^{14} \mathrm{C}\right)$ ) and assumed to be $\mathrm{CO}_{2}$, reached a high value of $27.5 \%$ of the protein hydrolysed after 90 min incubation. The diet in this experiment contained large amounts of starch grains and supported a large number of protozoa. In Expt B the lucerne diet supported a relatively small number of protozoa observed by microscopic examination and the initial uptake of protein by the rumen bacteria remained there with little change during the course of the incubation. Because of the lower specific radioactivity the absolute amount of ${ }^{14} \mathrm{C}$ adsorption onto the particuate matter was lower than in Expt A but expressed as a percentage of ${ }^{14} \mathrm{C}$-labelled fraction ! hydrolysed the values were higher than Expt $\mathrm{A}$. The amount of ${ }^{14} \mathrm{CO}_{2}$ lost was similar in the two experiments. 
Table 5. Sucrose densiiy gradients of particulate matter of rumen fluid during incubation with ${ }^{14} \mathrm{C}$-label'ed fraction I protein in vitro (Warburg apparatus) at $39^{\circ}$

(In Exp A cow rumen fluid obtained on hay + concentrate diet (original protein concentration in incubation $50 \mathrm{mg}$ nitroge $\mathrm{n} / \mathrm{l} ;{ }^{14} \mathrm{C}, 315$ disintegrations/min $\left(\times 10^{-3}\right)$ per $\left.\mathrm{ml}\right)$ in Expt $\mathrm{B}$ cow rumen fluid obtained on a lucerne diet (original protein concentration in incubation $490 \mathrm{mg}$ nitrogen/l; ${ }^{14} \mathrm{C}, 53.4$ disintegrations/min $\left(\times 10^{-3}\right)$ per $\left.\mathrm{ml}\right)$ )

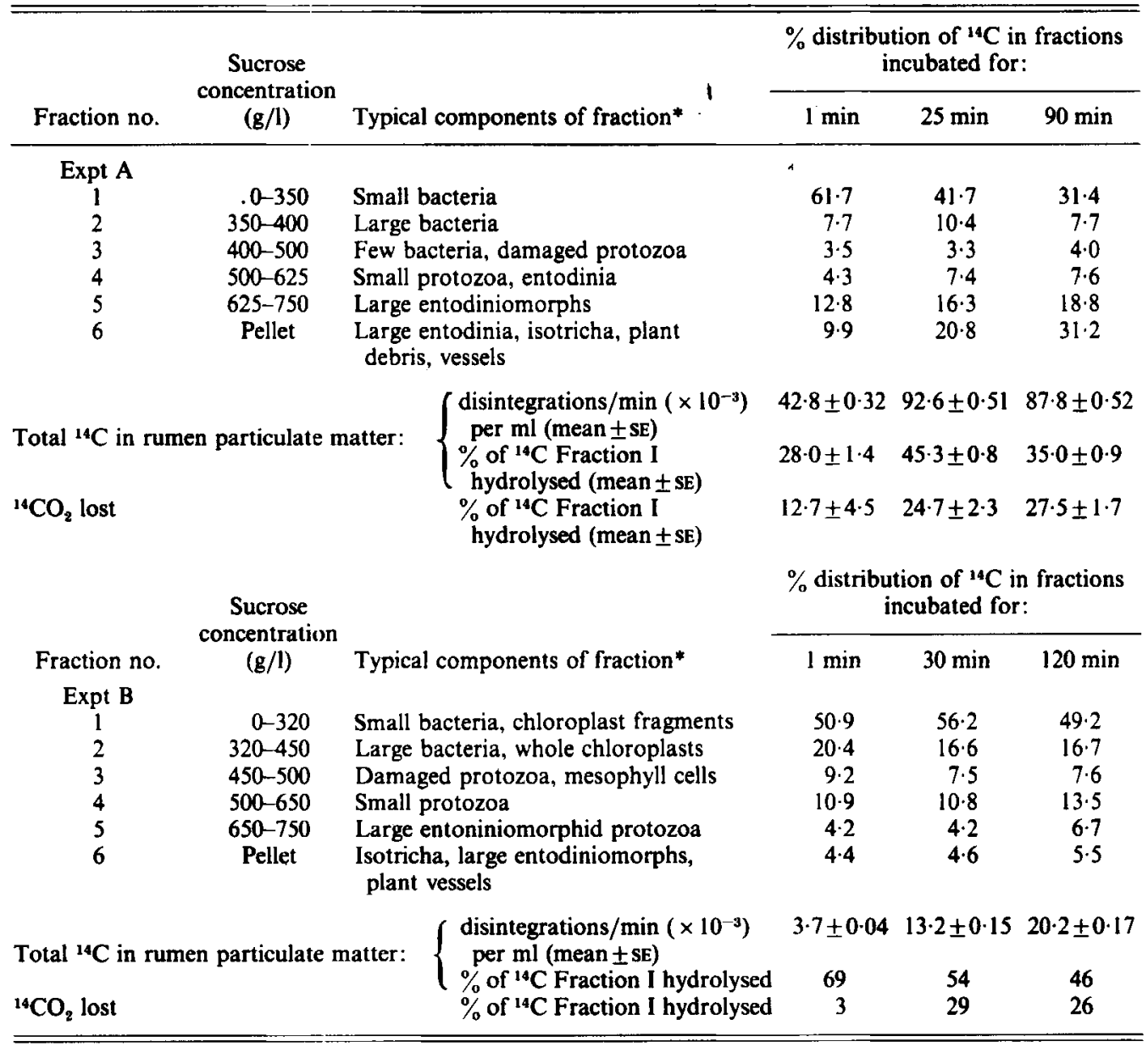

- See description by Mangan \& West (1977).

Products of proteolysis

Peptides. Polyacrylamide gel electrophoresis of supernatant fractions from reaction mixtures obtained by incubating rumen fluid with fraction I protein showed a decrease of the protein without the appearance of peptide bands, even when all the fraction I had been hydrolysed. Denaturing SDS gels showed only the large subunit, molecular weight 56000 , and small subunit, molecular weight 15000 , of fraction I decreasing with time with no formation of peptide bands. Chromatography on a Sephadex G200 column of supernatant fractions from ${ }^{14} \mathrm{C}$-labelled fraction I incubation showed the presence of one large band of fraction I near the void volume and only one radioactive product peak of molecular weight $<20000$. Comparison of 10 and 30 min incubations showed a decrease in fraction I coupled with an increase in product peak (Fig. 6). There were no intermediate peaks to indicate the 


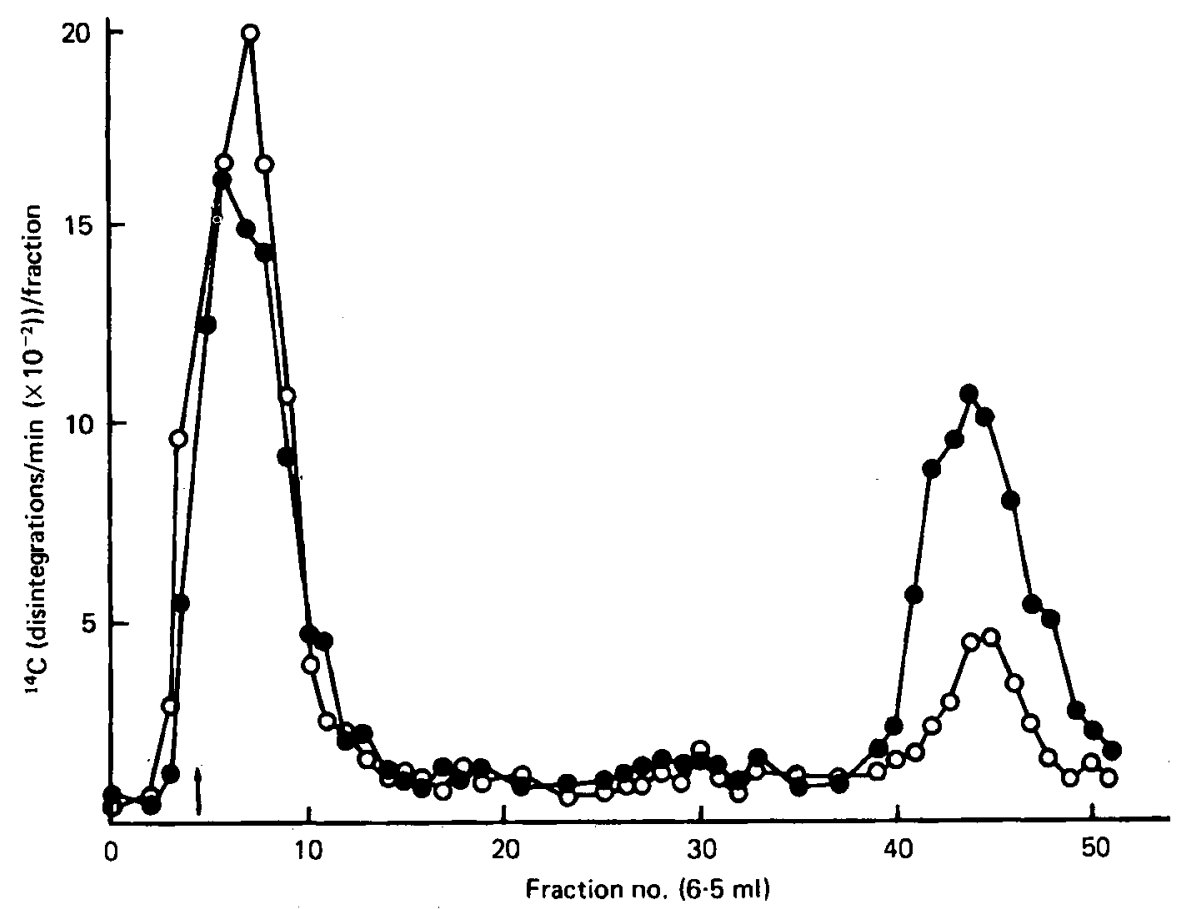

Fig. 6. Chromatography on Sephadex G200 column $(26 \times 600 \mathrm{~mm})$ of cell free supernatant fractions from in vitro incubation of ${ }^{14} \mathrm{C}$-labelled fraction I protein with rumen fluid from cow fed on lucerne (Medicago sativa $\mathrm{L}$ ) diet. Elution $50 \mathrm{~mm}$-phosphate buffer $\mathrm{pH} 7 \cdot 2$ at rate $20 \mathrm{ml} / \mathrm{h}$. $\uparrow$ indicates void volume. $(\mathrm{O}-\mathrm{O})$, $10 \mathrm{~min}$ incubation; $(\mathrm{O}-\mathrm{)}), 30 \mathrm{~min}$ incubation.

presence of large peptides. Chromatography on a range of Sephadex gels, G200, G75, G50, G25 and G10, failed to resolve the product peak until G10, which separates molecules smaller than 1000 molecular weight was used. The main peak in Fig. 7 derived from chromatography of an Amicon ultrafiltrate (molecular weight $<50000$ ) of rumen proteolysis of ${ }^{14} \mathrm{C}$-labelled fraction $\mathrm{I}$ for $60 \mathrm{~min}$ was mainly due to volatile fatty acids, since acidification and vacuum desiccation reduced the peak to less than $25 \%$ of the original. The non-volatile components would include amino acids and possibly small peptides. The elution points of glycine, leucine and propionic acid in Fig. 7 were determined by using ${ }^{14} \mathrm{C}$-labelled standards.

Amino acids. During proteolysis of fraction I in vivo only small transient peaks of free amino acids were seen in sheep on both diets, and leucine, valine and alanine were the most abundant. Using high specific activity ${ }^{14} \mathrm{C}$-labelled fraction I in the artificial rumen, most of the amino acids behaved like glycine, alanine, lysine and $\alpha$-amino butyric (Fig. 8) and were present only in small amounts. Rising concentrations were only observed during the initial rapid phase of fraction I proteolysis. Valine, leucine, isoleucine and ornithine, however, continued to rise during the whole period of protein breakdown and the concentrations reached values equivalent to approximately $10 \%$ of that present in the original protein. Arginine and histidine although present in fraction I in large amounts were not found free in rumen fluid during proteolysis. The specific radioactivities of all the amino acids released into the rumen fluid were closely similar to those in the original ${ }^{14} \mathrm{C}$-labelled fraction I protein and were consistent with the production of these amino acids solely from the protein degraded. The exception was alanine where specific activities in a number of 


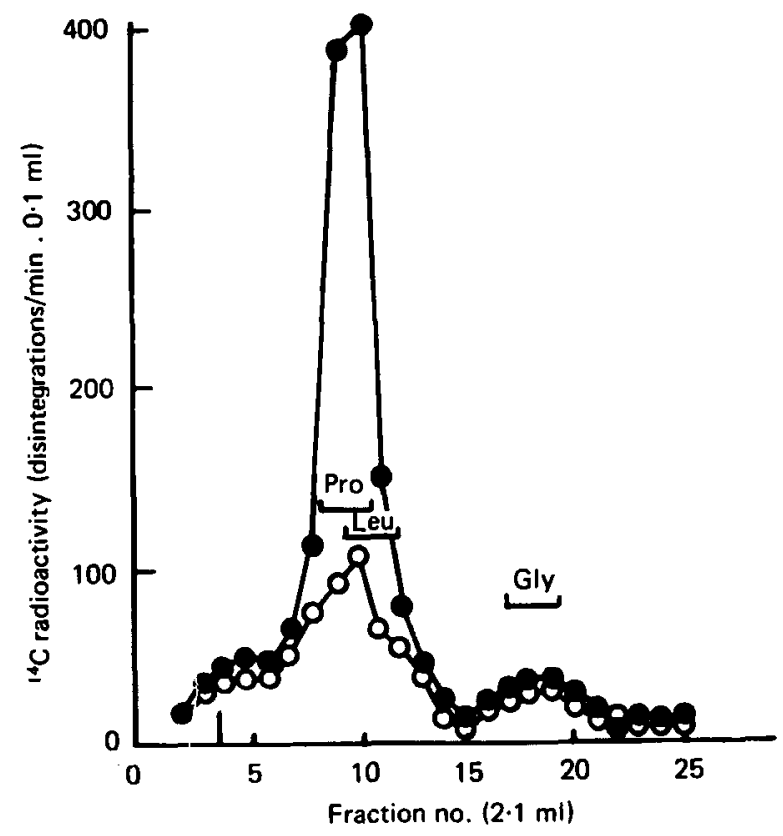

Fig. 7. Chromatogram on S:phadex G10 column $(10 \times 1000 \mathrm{~mm})$ of Amicon (CF50) ultrafiltrate of in vitro incubation of ${ }^{14} \mathrm{C}$-labelled fraction I protein with rumen fluid from cow fed on lucerne (Medicago sativa $\mathrm{L}$ ) diet. Elution $50 \mathrm{~mm}$-phosphate buffer $\mathrm{pH} 7.2$ at rate of $12.5 \mathrm{ml} / \mathrm{h}$. ( $-O)$, Rumen fluid $60 \mathrm{~min}$ incubation; $(\mathrm{O}-\mathrm{O})$, same sample after acidification and desiccation in vacuo; Pro, propionic acid; Leu, leucine; Gly, glycine.

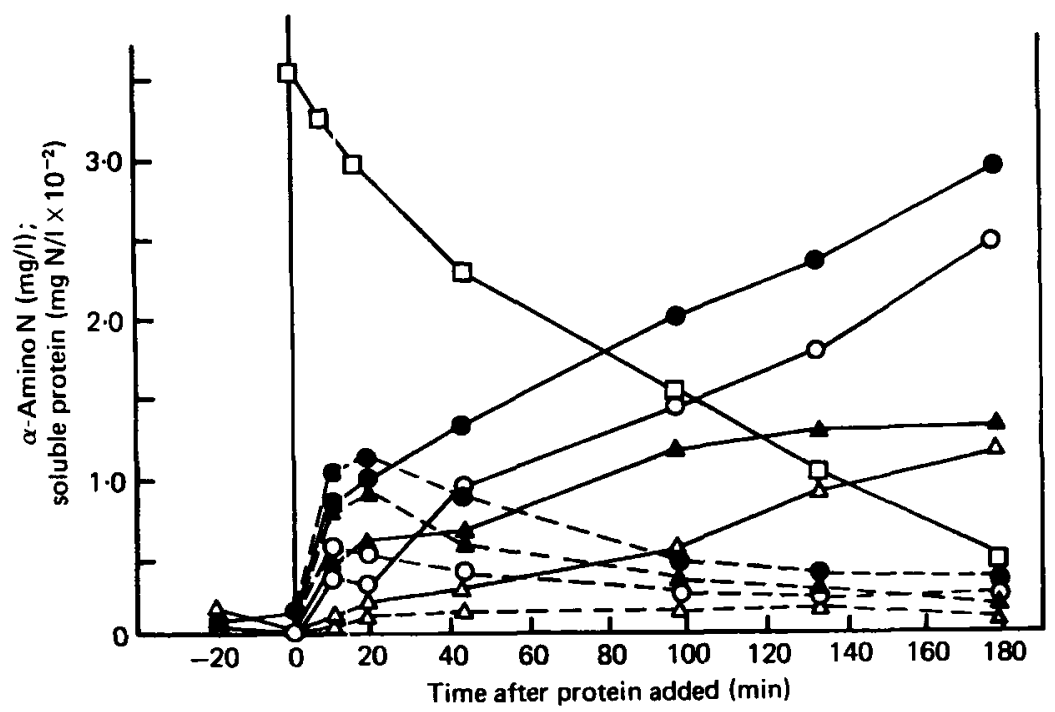

Fig. 8. Release of amino acids into rumen fluid during in vitro proteolysis of ${ }^{14} \mathrm{C}$-labelled fraction I protein with rumen fluid from sheep fzd on a hay + concentrate diet. $(\square-\square)$, Soluble protein nitrogen $\left(\times 10^{-1}\right)$; $(\mathbf{O}-\mathrm{O})$, valine; $(\mathrm{O}-\mathrm{O})$, leucine; $(\Delta-\Delta)$, ornithine; $(\Delta-\Delta)$, isoleucine; $\left(\boldsymbol{O}_{---}\right)$, alanine; $(\bigcirc---\bigcirc)$, glycine; $\left(\boldsymbol{\Delta}^{---\Delta}\right)$, lysine; $(\Delta---\Delta), \alpha$-amino butyric. 
Table 6. Release of free amino acids during proteolysis of ${ }^{14} \mathrm{C}$-labelled fraction I protein as affected by initial protein concentration

(In vitro (Warburg apparatus) with rumen fluid from cow on hay + concentrate diet: incubation time $40 \mathrm{~min}$ at $39^{\circ}$ )

\begin{tabular}{|c|c|c|c|c|c|c|c|c|}
\hline & \multicolumn{8}{|c|}{ Incubation no. } \\
\hline & 1 & 2 & 3 & 4 & 5 & $5\left({ }^{14} \mathrm{C}\right) \dagger$ & 6 & $6\left({ }^{14} \mathrm{C}\right) \dagger$ \\
\hline $\begin{array}{l}\text { Initial protein concentration } \\
(\mathrm{mg} \text { nitrogen } / \mathrm{l})\end{array}$ & 0 & 85 & 130 & 220 & 320 & & 440 & \\
\hline $\begin{array}{l}\text { Initial }{ }^{14} \mathrm{C} \text { (disintegrations } \\
/ \mathrm{min}\left(\times 10^{-3}\right) \text { per } \mathrm{ml} \text { ) }\end{array}$ & - & $12 \cdot 35$ & $18 \cdot 00$ & $29 \cdot 72$ & $43 \cdot 29$ & & $64 \cdot 38$ & \\
\hline \multicolumn{9}{|l|}{$\begin{array}{l}\text { Initial velocity of proteolysis } \\
(\mathrm{mg} \text { nitrogen } / 1 / \mathrm{min})\end{array}$} \\
\hline Mean & - & 1.41 & 1.82 & $2 \cdot 28$ & $2 \cdot 35$ & & $2 \cdot 46$ & \\
\hline SE & & $0 \cdot 11$ & 0.11 & $0 \cdot 12$ & 0.05 & & 0.05 & \\
\hline $\begin{array}{l}\text { Soluble protein at } 40 \mathrm{~min}: \\
{ }^{14} \mathrm{C}(\text { disintegrations } / \mathrm{min} \\
\left.\left(\times 10^{-3}\right) \text { per } \mathrm{ml}\right)\end{array}$ & - & $7 \cdot 06$ & $11 \cdot 12$ & $21 \cdot 38$ & $32 \cdot 46$ & & 57.63 & \\
\hline Nitrogen $(\mathrm{mg} / \mathrm{l})$ & - & 50 & 82 & 158 & 240 & & 360 & \\
\hline \multicolumn{9}{|l|}{$\begin{array}{l}\text { Amino acid analysis } \\
(\mu \mathrm{g} \alpha \text {-amino } N / \mathrm{ml})\end{array}$} \\
\hline Aspartic acid & $*$ & $*$ & $*$ & $\mathbf{0}$ & $0 \cdot 12$ & $0 \cdot 14$ & $0 \cdot 12$ & $0 \cdot 12$ \\
\hline Threonine & * & - & * & * & $*$ & 0.08 & • & - \\
\hline Serine & $*$ & * & * & $0 \cdot 10$ & 0.14 & $0 \cdot 12$ & $0 \cdot 18$ & $0 \cdot 16$ \\
\hline Glutamic acid & * & - & * & $*$ & * & 0.08 & $0 \cdot 14$ & 0.08 \\
\hline Glycine & * & * & 0.18 & $0 \cdot 25$ & 0.37 & 0.36 & 0.40 & 0.36 \\
\hline Alanine & $*$ & 0.14 & 0.37 & 0.54 & 0.88 & 1.86 & 0.78 & 1.92 \\
\hline Valine & $*$ & $0 \cdot 23$ & 0.54 & $0 \cdot 84$ & $1 \cdot 12$ & 0.98 & 1.26 & 0.90 \\
\hline$\alpha$-Amino butyric & 0 & $\mathbf{0}$ & * & $0 \cdot 14$ & 0.23 & $0 \cdot 18$ & $0 \cdot 28$ & 0.20 \\
\hline Isoleucine & 0 & $*$ & $0 \cdot 16$ & 0.27 & 0.43 & 0.34 & 0.41 & 0.34 \\
\hline Leucine & 0 & $0 \cdot 214$ & 0.38 & 0.62 & 0.82 & 0.84 & 1.04 & 1.00 \\
\hline Phenylalanine & 0 & 0 & 0.10 & 0.12 & 0.30 & 0.22 & 0.26 & 0.26 \\
\hline Tyrosine & 0 & 0 & $*$ & 0.16 & 0.28 & 0.24 & 0.38 & 0.42 \\
\hline Ornithine & 0 & $0 \cdot 16$ & 0.35 & 0.54 & $0-88$ & 0.68 & 0.90 & 0.80 \\
\hline Lysine & $*$ & 0.12 & 0.31 & 0.43 & 0.70 & 0.56 & 0.74 & 0.66 \\
\hline
\end{tabular}

* Detected but too small to measure.

$\dagger$ Calculated $\mathrm{N}$ from ${ }^{14} \mathrm{C}$ content and specific activity of original protein.

experiments were two to three times that in the original protein. This anomaly is probably caused by the presence of an unknown compound of high specific activity, but low ninhydrin colour yield, running with the same elution point as alanine on the amino acid analyser. Amino sugars are a possibility. With increasing initial concentrations of fraction I there was an increase in the liberation of free amino acids and Table 6 shows the results of a series of incubations using rumen fluid from a cow $5 \mathrm{~h}$ after feeding the hay + concentrate diet. The Warburg apparatus was used with a $\mathbf{4 0}$ min incubation period.

Occasionally abnormally-high concentrations of free amino acids were observed at the commencement of incubations, and particularly when associated with abundance of $\delta$-amino valerate, $\gamma$-amino butyrate, proline and $\epsilon, \epsilon$-diamino pimelate were related to damage to the rumen fluid such as exposure to oxygen and temperature shock. Amino acid analysis was used as a check on technique. Measurement of proteolysis by the production of free amino acids, particularly with unlabelled substrates, as used by Broderick (1978) must therefore be treated with caution.

$V F A$. The presence of large amounts of ${ }^{14} \mathrm{C}$-labelled VFA indicated in Fig. 7 was investigated further and in a series of experiments the acid-diethyl-ether-soluble components 


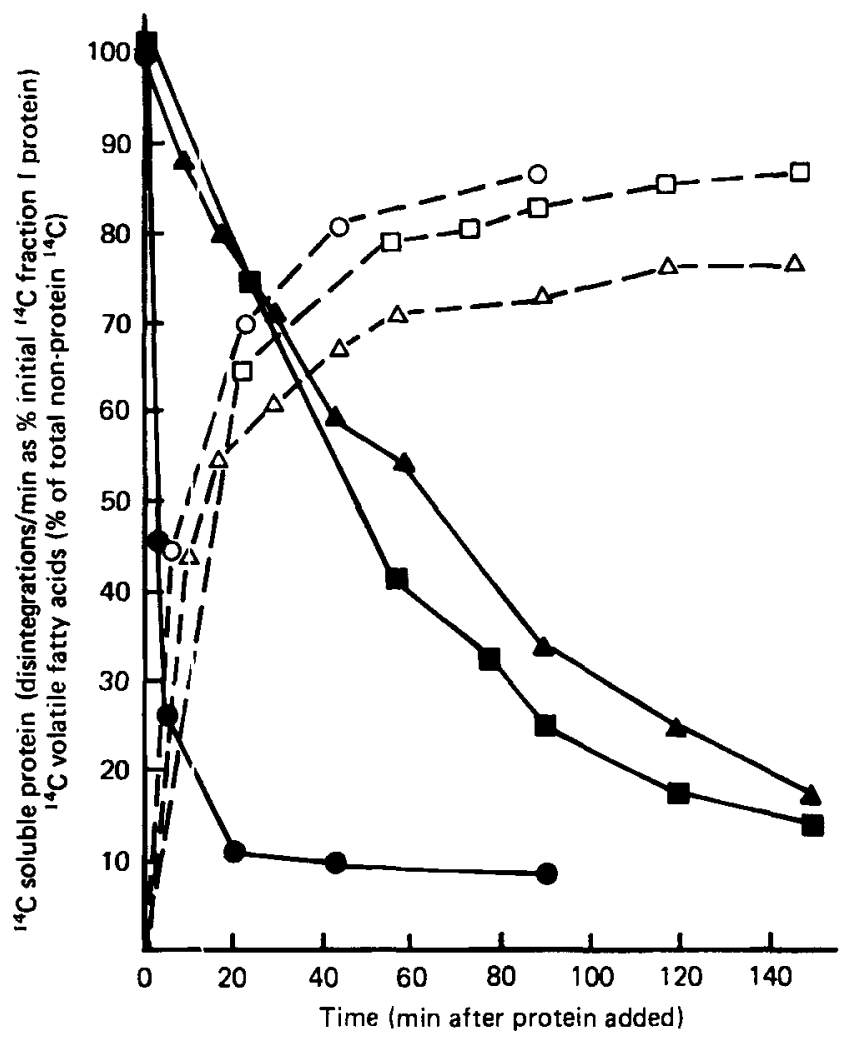

Fig. 9. Production of ${ }^{14} \mathrm{C}$-labelled volatile fatty acids (VFA; acid diethyl ether soluble) during fermentation of ${ }^{14} \mathrm{C}$-labelled fraction $\mathrm{I}$ protein in vitro, at three initial protein concentrations. $(\mathrm{O}-\mathrm{O})$, fraction I; $(\mathrm{O}-\mathrm{O})$, VFA, initial concentration fraction $\mathrm{I}<40 \mathrm{mg} \mathrm{N} / \mathrm{l}$, Warburg apparatus; ( $-\square)$, fraction I; ( $\square-\square)$, VFA, initial concentration fraction I $110 \mathrm{mg} \mathrm{N} / \mathrm{l}$, artificial rumen; ( $\mathbf{C}-\mathbf{\Delta})$, fraction I; $(\Delta-\Delta)$, VFA, initial concentration fraction I $250 \mathrm{mg} \mathrm{N} / 1$, artificial rumen.

Table 7. The composition of the volatile fatty acids (VFA) produced during in vitro proteolysis (Warburg apparatus) of high specific activity ${ }^{14} \mathrm{C}$-labelled fraction I protein

(Rumen fluid from cow on hay + concentrate diet; VFA extracted by acid diethyl ether and analysed by gas-liquid chromatography. For details, see p. 42)

\begin{tabular}{|c|c|c|c|c|c|}
\hline Time $\left(\operatorname{mi}_{11}\right) \ldots$ & $\mathbf{0}$ & 10 & 30 & 60 & 100 \\
\hline Acetate: $\%{ }^{14} \mathrm{C}$ & 0 & $36 \cdot 4$ & $29 \cdot 9$ & $27 \cdot 3$ & $28 \cdot 2$ \\
\hline$\%$ mass & $41 \cdot 4$ & $40 \cdot 0$ & $42 \cdot 9$ & $36 \cdot 0$ & $40 \cdot 5$ \\
\hline Propionate: $\%{ }^{14} \mathrm{C}$ & 0 & 22.9 & $24 \cdot 4$ & $27 \cdot 7$ & $26 \cdot 5$ \\
\hline$\%$ mass & $27 \cdot 1$ & $26 \cdot 0$ & $26 \cdot 8$ & $27 \cdot 0$ & $26 \cdot 0$ \\
\hline Isobutyrate: $\%{ }^{14} \mathrm{C}$ & 0 & 9.9 & $7 \cdot 8$ & $9 \cdot 6$ & $7 \cdot 7$ \\
\hline$\%$ mass & $2 \cdot 6$ & 3.4 & $2 \cdot 4$ & $2 \cdot 6$ & $2 \cdot 8$ \\
\hline Butyrate: $\%{ }^{i 4} \mathrm{C}$ & 0 & $11 \cdot 1$ & $8 \cdot 9$ & 11.6 & $11 \cdot 4$ \\
\hline$\%$ inass & $22 \cdot 0$ & $23 \cdot 0$ & $20 \cdot 4$ & $26 \cdot 0$ & $24 \cdot 5$ \\
\hline 2-methyl and 3-methyl & & & & & \\
\hline butyrate: $\%{ }^{14} \mathrm{C}$ & 0 & $19 \cdot 8$ & $28 \cdot 0$ & $20 \cdot 8$ & $21 \cdot 5$ \\
\hline$\%$ mass & 3.4 & $3 \cdot 2$ & $3 \cdot 2$ & $4 \cdot 4$ & $3 \cdot 7$ \\
\hline Valerate: $\%{ }^{14} \mathrm{C}$ & 0 & 0 & 0 & $3 \cdot 0$ & $4 \cdot 5$ \\
\hline$\%$ rnass & 3.7 & $3 \cdot 5$ & $3 \cdot 5$ & 3.9 & $3 \cdot 7$ \\
\hline $\begin{array}{l}\% \text { Recovery of }{ }^{14} \mathrm{C} \text { in } \\
\text { acid diethyl ether }\end{array}$ & & & & & \\
\hline extract & 96 & 95 & 102 & 93 & 98 \\
\hline
\end{tabular}


Table 8. Proteolysis of ${ }^{14} \mathrm{C}$-labelled fraction I protein by isolated protozoal fraction of bovine rumen fluid in vitro (Warburg)

(Diet was hay + concentrates)

\begin{tabular}{|c|c|c|c|c|}
\hline & $\begin{array}{l}\text { Incubation } \\
\text { time (h) }\end{array}$ & $\begin{array}{c}\text { Total soluble }{ }^{14} \mathrm{C} \\
\text { (disintegrations } \\
/ \min \left(\times 10^{-3}\right) \\
\text { per } \mathrm{ml})\end{array}$ & $\begin{array}{c}\text { Non-protein }{ }^{44} \mathrm{C} \\
\text { (disintegrations } \\
/ \text { min }\left(\times 10^{-2}\right) \\
\text { per } \mathrm{ml})\end{array}$ & $\begin{array}{c}\text { Soluble protein }{ }^{1+} \mathrm{C} \\
\text { (disintegrations } \\
/ \min \left(\times 10^{-3}\right) \\
\text { per } \mathrm{ml})\end{array}$ \\
\hline $\begin{array}{l}\text { Salts solution } \\
\text { (Coleman, 1975) }\end{array}$ & 2 & $161 \cdot 3$ & 5.0 & 156.4 \\
\hline Protozoal fraction ${ }^{*}$ & 2 & $158 \cdot 8$ & 12.9 & $145 \cdot 9$ \\
\hline Protozoal fraction* & 4 & 152.2 & $15 \cdot 1$ & $137 \cdot 1$ \\
\hline Crude rumen fluid & 1.5 & $143 \cdot 4$ & $63 \cdot 3$ & $80 \cdot 1$ \\
\hline Protozoa-free rumen fluid & 1.5 & 152.9 & 28.5 & $124 \cdot 4$ \\
\hline
\end{tabular}

* Adjusted to original rumen fluid concentration.

of ${ }^{14} \mathrm{C}$-labelled fraction I proteolysis products were found to rise rapidly as proteolysis proceeded (Fig. 9) and constituted $72-83 \%$ of the non-protein ${ }^{14} \mathrm{C}$ after $1 \mathrm{~h}$ incubation. The composition of the VFA during proteolysis with bovine rumen fluid is given in Table 7 . Within the first 30 min of incubation the pattern of ${ }^{14} \mathrm{C}$-labelled VFA was fixed and the specific ${ }^{14} \mathrm{C}$ radioactivity changed little as the fermentation proceeded. Acetate, propionate and the methyl butyrates were the major acids and were produced in approximately equal amounts, and constituting $82 \%$ of the total. Isobutyrate and butyrate were intermediate in concentration and valerate was present in very small amounts and incorporated little ${ }^{14} \mathrm{C}$.

Protozoa. Using a mixed population of rumen protozoa, isolated intact and active, it was found that rates of proteolysis were low compared to those observed for whole rumen fluid. Table 8 shows that the protozoal population had less than $10 \%$ of the activity of whole rumen fluid and only approximately $20 \%$ of the activity of the rumen fluid sample from which the protozoa had been removed. Some bacterial contamination was still present in the protozoal preparations.

\section{DISCUSSION}

In view of the complex nature of rumen microflora it is surprising that proteolysis with crude rumen fluid can be treated as a simple enzyme-catalysed reaction. The present work confirms that proteolytic activity in the rumen is almost entirely associated with bacterial cells and that cell-free rumen fluid and protozoa have little activity. Previous suggestions that protozoa play a larger primary role in rumen proteolysis is not supported by the present studies, although the secondary role of bacterial engulfment is confirmed. Studies on isolated proteolytic rumen bacteria (Blackburn \& Hullah 1974; Hazlewood \& Nugent 1978) support the previously mentioned findings.

A recent study of proteolysis in the rumen by Broderick (1978) used the reaction with hydrazine sulphate to trap amino acids and ammonia as end products of protein breakdown in the rumen. An in vitro incubation using strained rumen fluid was used and gave 1st-order kinetics for rumen proteolysis. However, the techniques produced rates of proteolysis much lower than in vivo. The earlier work on casein (Mangan, 1972) can also be interpreted as showing lst-order kinetics for in vivo rumen proteolysis of this protein.

lst-order kinetics were observed only at low concentrations of fraction I protein and over a wider range of concentrations a velocity $v$. substrate concentration curve characteristic of enzyme-catalysed systems was obtained. With rumen fluid from a cow on the hay + concentrate diet a $V_{\max }$ of $2.6 \mathrm{mg}$ protein $\mathrm{N} / 1$ rumen fluid per min and a $K_{m}$ of $75 \mathrm{mg} \mathrm{N} / 1$ were obtained. Calculation for a cow with a rumen volume of 501 would allow proteolysis 
of approximately $50 \mathrm{~g}$ fraction $\mathrm{I} / \mathrm{h}$. In a lucerne-fed cow the concentration of soluble protein in the rumen considerably exceeds the range of $K_{m}$ values indicated in these studies, so that the rate of proteolysis would approach the $V_{\max }$ for considerable periods. Because of an approximate 7-fold increase in proteolytic activity of the rumen fluid of the lucerne-fed cow, rates could not be measured accurately but from the previously-mentioned values the rumen could possibly break down as much as $350 \mathrm{~g}$ fraction $\mathrm{I} / \mathrm{h}$. The amount of free fraction I protein to escape the rumen undegraded is therefore probably very small.

The adsorption of protzin onto the rumen bacteria as indicated in this study would confer a considerable advantage to organisms in competition for protein in free solution. On the assumption that protein adsorption is partly due to reaction with the proteolytic enzyme itself, reduction of this binding may be an approach to control of rumen proteolysis.

The absence of any peptides in the products of fraction I proteolysis indicates that under the conditions in this work the rate-limiting step is the formation of peptides from original protein rather than the further breakdown to free amino acids. Mangan (1972) has shown that with the more rapidly hydrolysed casein, peptides do appear in the rumen fluid of cattle. The pattern of free amino acids released into the rumen fluid shows a predominance in the branched-chain amino acids, valine, leucine and isoleucine, similar to the results of Mangan (1972) with casein, where valine, leucine, isoleucine and lysine were present in rumen fluid in large quantities. The formation of large amounts of ornithine during the degradation of fraction I is probably a reflection of the large amount of arginine present in fraction I.

The precursors of valine, leucine and isoleucine in the rumen are isobutyrate, 3-methyl butyrate and 2-methyl butyrate respectively (Allison, 1969) and the use of ${ }^{14} \mathrm{C}$-labelled fraction I shows that these branched-chain VFAs are produced in quantity and the concentrations maintained in the rumen for considerable periods of time, sufficient for resynthesis of these amir.o acids.

The application of the kinetic approach to the study of proteolysis in the rumen presents the possibility of precise comparison of the rates for different soluble proteins, their interactions and possible control of protein breakdown in the rumen.

The authors are grateful to Dr F. A. Harrison for rumen fistulation of the animals and for veterinary advice, and wish to thank $\mathrm{Mr} \mathrm{D}$. J. Jordan for analytical assistance; $\mathrm{MrD}$. W. Grime for operation of the growth chamber of the production of ${ }^{14} \mathrm{C}$-labelled lucerne and Dr P. F. V. Ward for gas-liquid chromatography of volatile fatty acids. One of us, J.H.A.N., wishes to express his gratitude to the Meat and Livestock Commission for a Postgraduate Fellowship and to Dr B. A. Cross, Director of the Institute, for permission to carry out the research.

\section{REFERENCES}

Allison, M. J. (1969). J. Anim. Sci. 29, 797.

Black, J. L., Beever, D. E., Faichney, G. J., Howarth, B. R. \& Graham, N.McC. (1981) Argic. Systems. (In the Press).

Blackburn, T. H. \& Hullah, W. A. (1974). Can. J. Microbiol. 20, 435.

Blaxter, K. L. \& Martin, A. K. (1962). Br.J. Nutr. 16, 397.

Broderick, G. A. (1978). J. Nutr. 108, 181.

Burroughs, W., Trenkle, A. \& Vetter, R. L. (1974). Vet. Med. Small Anim. Clin. 69, 713.

Chalmers, M. I., Cuthbertson, D. P. \& Synge, R. L. M. (1954). J. agric. Sci., Camb. 44, 254.

Coleman, G. S. (1975). In Digesion and Metabolism in the Ruminant, p. 149 [1. W. McDonald and A. C. I. Warner, editors]. University of New England Publishing Unit: Armidale, N.S.W., Australia.

Dawson, R. M. C. \& Hemingten, N. (1974). Br. J. Nutr. 32, 327.

Harrison, F. A. (1974). J. Physiol., Lond. 242, 20 P.

Hazlewood, G. P., Jones, G. A. \& Mangan, J. L. (1981). J. gen Microbiol. (In the Press).

Hazlewood, G. P. \& Nugent, J. H. A. (1978). J. gen. Microbiol. 106, 369.

Henderickx, H. \& Martin, J. (1963). Compt. Rend. Rech. IRSIA, Brussels 31, 7. 
Hydén, S. (1956). Kungl. Lantbr. Annal 22, 139.

James, A. T. \& Piper, E. A. (1963). Analyt. Chem. 35, 515.

Jarrett, I. G. (1948). J. Coun. Scient. ind. Res. Aust. 21, 311.

Jones, W. T. \& Mangan, J. L. (1976). J. agric. Sci. Camb. 86, 495.

Kawashima, N. \& Wildman, S. G. (1970). A. Rev. Plant Physiol. p. 325.

McArthur, J. M. \& Miltimore, J. F. (1961). Can. J. Anim. Sci. 41, 187.

McDonald, I. W. \& Hall, R. J. (1959). Biochem. J. 67, 400.

McDougall, E. I. (1948). Biochem. J. 43, 99.

Mahadevan, S., Erfle, J. D. \& Sauer, F. D. (1980). J. Anim. Sci. 50, 723.

Mangan, J. L. (1972). Br. J. Nutr. 27, 261.

Mangan, J. L.\& Bounden, J. (1965). 3rd Technicon Amino Acid Colloquium p. 46. Tarrytown, New York: Technicon Instruments Corp.

Mangan, J. L., Jones, W. T., Nugent, J. H. A. \& Jordan, D. J. (1977). Proc. 11th FEBS Mtg, Copenhagen A3-2, 903.

Mangan, J. L., Vetter, R. L., Jordan, D. J. \& Wright, P. C. (1976). Proc. Nutr. Soc. 35, 95A.

Mangan, J. L. \& West, J. (1977). J. agric. Sci., Camb. 89, 3.

Miller, E. L., Balch, C. C., Orskov, E. R., Roy, J. H. B. and Smith, R. H. (1977). Proc. 2nd int. Symp. Protein Metabolism and Nutrition, Pudoc, Wagenigen p. 137.

Nugent, J. H. A. (1978). Studies on Proteolysis in the Rumen. PhD Thesis, University of Cambridge.

Nugent, J. H. A. \& Mangan, J. L. (1978). Proc. Nutr. Soc. 37, 48A.

Reid, M. S. \& Bieleski, R. L. (1968). Analyt. Biochem 22, 374.

Roy, J. B. H., Balch, C. C., Miller, E. L., Orskov, E. R. \& Smith, R. H. (1977). Proc. 2nd int. Symp. Protein Metabolism and Nutrition, Pudoc, Wagenigen p. 126.

Shafa, F. \& Salton, M. R. J. (1960). J. gen. Microbiol. 22, 137.

\section{EXPLANATION OF PLATE}

Plate 1. Artificial rumen apparatus. 1, Flanged pyrex glass vessel, volume $500 \mathrm{ml}$ and flanged lid with five entry ports; 2, magnetic stirrer-heater and PTFE coated magnetic bar; 3, adjustable-contact thermometer controlling heater through thermostat control; 4, sample probe with stainless-steel strainer (30 mesh; 32 SWG) used with hypodermic syringe or continuous peristaltic pump with optional $\mathrm{pH}$-stat and automatic titrator; 5 , dialyser, or second sampler if used without cuprophan membrane; 6 , gas inlet-outlet continuously flushed with nitrogen-carbon dioxide $(95: 5, v / v) ; 7$, expanded-polystyrene insulation box, front removed. 


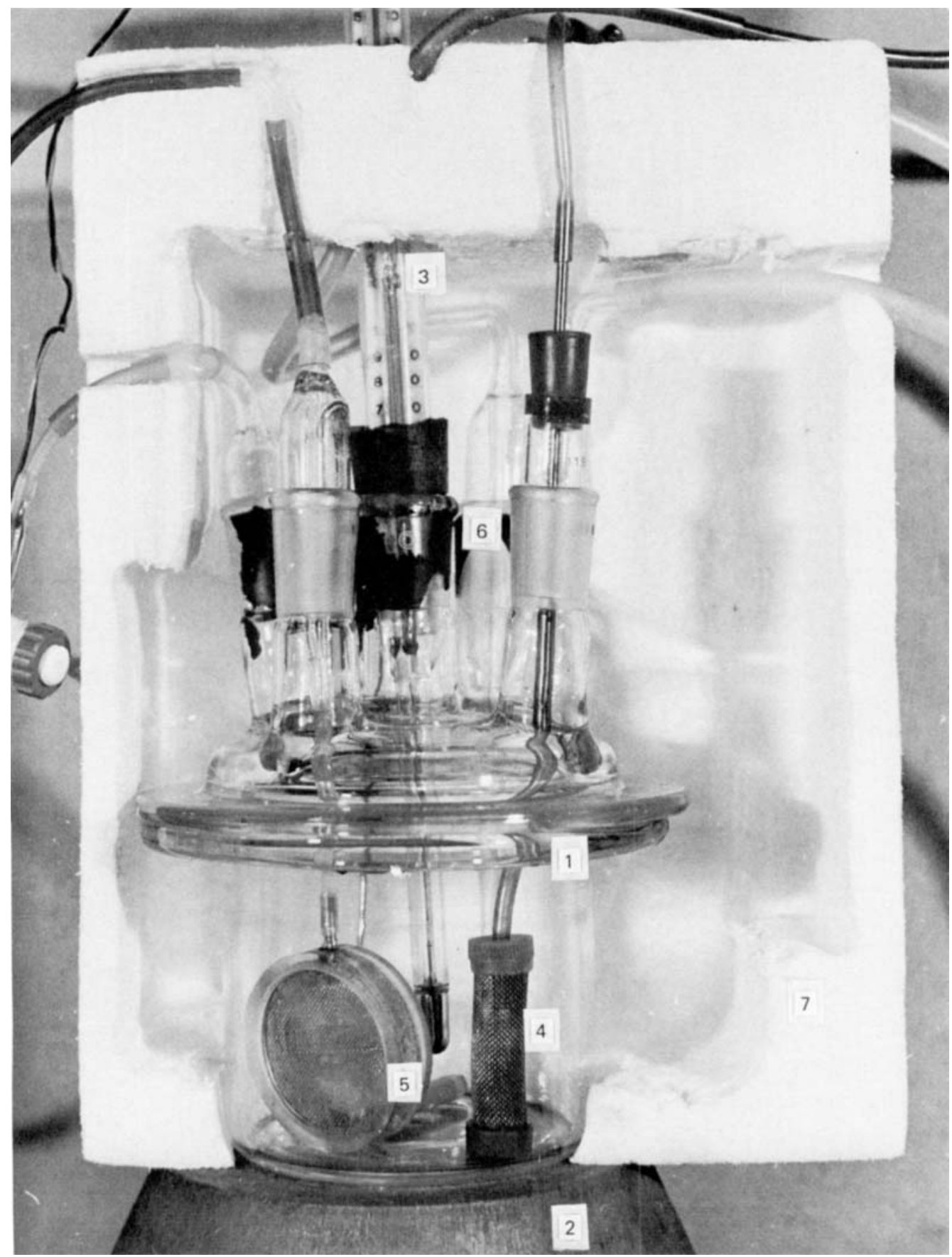

